\title{
INFLUENCE OF MENOPAUSE ON SERUM LIPOPROTEIN (A)[LP(a)
}

\author{
SULTANA N ${ }^{1}$, AHMED $\mathrm{S}^{2}$, PARVIN $\mathrm{S}^{3}$, MAHAL M ${ }^{4}$, CHOWDHURY NS ${ }^{5}$
}

\begin{abstract}
:
A case control study on seventy women from community was designed and carried out in the Department of Biochemistry, Dhaka Medical College, Dhaka, from July 2005 to June 2006, to study of serum lipoprotein(a) $\left[L p_{(a)}\right] . L p_{(a)}$ is a $L D L$ like special type of lipoprotein which is claimed to be an atherogenic lipoprotein by many researches. Among the study subjects, cases were 30 post menopausal women (group A) and controls were 40 women of reproductive age, divided into two groups; group $B_{1}$ (25-35 years) and group $B_{2}$ (36-45 years). Serum $L p_{(a)}$ of all the study subjects was measured. The mean serum $L p_{(a)}$ concentration in group $A, B_{1}$ and $B_{2}$ were $35.77 \pm 31.90,18.40 \pm 11.46$ and $19.20 \pm 14.89 \mathrm{mg} / \mathrm{dl}$, respectively. The results were compared between different groups by unpaired Student's ' $t$ ' test. The $L p_{(a)}$ concentration of group A compared to group $B_{1}$ and $B_{2}$ were found to be significantly higher $(P<0.05)$. But the mean serum $L p_{(a)}$ concentration of group $B_{1}$ and $B_{2}$ did not differ significantly.
\end{abstract}

Key words: Serum lipoprotein (a) $\left[L p_{(a)}\right]$, menopause

J Dhaka Med Coll. 2011; 20(1) : 102-106.

\section{Introduction:}

Menopause is defined as the permanent cessation of menstruation due to loss of ovarian activity. Many physiological changes occur in women after menopause; including hormonal and metabolic changes. Hormonal changes include diminished secretion of estrogen and progesterone, increased pituitary secretion of luteinizing and follicle stimulating hormone ${ }^{1}$. It has been observed that serum lipid and lipoproteins are significantly altered as a consequence of hormonal changes ${ }^{2}$. Lipoproteins are conjugated proteins consisting of lipids and special protein known as apoprotein. The classical lipoproteins are chylomicron, very low density lipoprotein (VLDL), low density lipoprotein (LDL) and high density lipoprotein (HDL). Besides these classical types, almost all people have a special type of non classical lipoprotein called lipoprotein(a) $\left[\mathrm{Lp}_{(\mathrm{a})}\right] . \mathrm{Lp}_{(\mathrm{a})}$ concentration in human plasma is significantly correlated with the risk of atherosclerotic heart disease, which was described by Berg in 1963. Regarding plasma lipid modifications after menopause,
$\mathrm{LDL}$, triglyceride and $\mathrm{Lp}_{(\mathrm{a})}$ tend to increase, where as HDL decreases. Altered lipid profile is responsible for atherosclerosis ${ }^{2}$. Among the classical serum lipoproteins, LDL, serum total cholesterol and triglycerides are primarily atherogenic, but $\operatorname{Lp}_{(\mathrm{a})}$ is both atherogenic as well as thrombogenic. Therefore, $\mathrm{Lp}_{(\mathrm{a})}$ acts as a dual cardiovascular and cerebrovascular pathogen ${ }^{3} \cdot \mathrm{Lp}_{(\mathrm{a})}$ is a low density lipoprotein. Triglyceride, cholesterol and phospholipid together constitute its lipid portion, and the protein portions are apoprotein $\mathrm{B}-100$ and apoprotein(a). Apo $($ a) is a glycoprotein and it is homology to plasminogen, differentiates it from other apolipoprotein ${ }^{4}$.

It is hypothesized that elevated $\mathrm{Lp}_{(\mathrm{a})}$ slows the breakdown of blood clots that trigger heart attacks because it competes with plasminogen for the binding of plasminogen activators. $\mathrm{Lp}_{(\mathrm{a})}$ and LDL has got the same receptor, but due to low affinity of $\mathrm{Lp}_{(\mathrm{a})}$ for $\mathrm{LDL}$ receptor, it accumulates in vessel walls and directly increase the arterial permeability and traverse the endothelium to the intima. In the intima,

1. Dr. Nasima Sultana, Associate Professor, Department of Biochemistry, Dhaka Medical College, Dhaka.

2. Dr. Selina Ahmed, Professor \& Head, Department of Biochemistry, Dhaka Medical College, Dhaka.

3. Dr. Shamima Parvin, Assistant Professor, Department of Biochemistry, Sir Salimullah Medical College, Dhaka.

4. Dr. Monzarin Mahal, Lecturer, Department of Biochemistry, Shaheed Suhrwardy Medical College, Dhaka.

5. Dr. Neelufer Sultana Chowdury, Assistant Professor, Department of Biochemistry, Chest Disease Hospital, Dhaka. Correspondence: Dr. Nasima Sultana, Associate Professor, Department of Biochemistry, Dhaka Medical College, Dhaka. Cell Phone: +8801715992188, Email: snasima62@yahoo.com 
it binds the tissue matrix components facilitating foam cell formation. $\operatorname{Lp}_{(\mathrm{a})}$ comes in contact with the endothelial injured sites, gets oxidative modification resulting in uptake by macrophages, leading to accelerated foam cell formation ${ }^{5}$. It is the key event for atherosclerosis. Another mechanism for the atherogenic activity of $\mathrm{Lp}_{(\mathrm{a})}$ is the promotion of smooth muscle cell proliferation ${ }^{6}$.

Both retrospective and prospective population studies have shown a positive association between plasma levels of $\mathrm{Lp}_{(\mathrm{a})}$ and risk of CAD and stroke ${ }^{7,8}$. After menopause, CAD risk progressively increases due to lack of oestrogen. Because oestrogen can protect females to a large extent from the potentially deleterious effects of high $\operatorname{Lp}_{(\mathrm{a})}$ until menopause ${ }^{9}$. This mechanism of action of oestrogen has been explained by some researchers. Oestrogen influence the assembly of $\operatorname{apo}_{(\mathrm{a})}$ to $\mathrm{apo}_{(\mathrm{B})}$, which is believed to occur through a disulfide linkage in the hepatocyte. Oestrogen lower $\operatorname{Lp}_{(\mathrm{a})}$ through an increased clearance ${ }^{10}$. Therefore, oestrogen may protect females in reproductive age, but this advantage is lost after menopause.

In conventional approaches, triglyceride, total cholesterol, LDL-cholesterol and HDLcholesterol were measured as risk indicator for CAD. But a good number of patients suffering from the major clinical events of atherosclerosis surprisingly present a normal lipid profile or normal lipoprotein level ${ }^{11}$. In these classical normolipidaemic patients, $\mathrm{Lp}_{(\mathrm{a})}$ has been found to be significantly correlated with increased $\mathrm{Lp}_{(\mathrm{a})}$, so increased $\mathrm{Lp}_{(\mathrm{a})}$ is a useful marker for CAD severity among postmenopausal women. Again , $\mathrm{Lp}_{(\mathrm{a})}$ is a better marker for CAD risk than LDL because $\mathrm{Lp}_{(\mathrm{a})}$ is considered a risk factor at a concentration of $20 \mathrm{mg} / \mathrm{dl}$, where as LDL-cholesterol is considered to be a risk factor for atherosclerosis at about 300 to $400 \mathrm{mg} / \mathrm{dl}$, which is 15 to 20 times as much as $\operatorname{Lp}_{(a)} 12$. Therefore, the present study was designed to find out the importance of $\mathrm{Lp}_{(\mathrm{a})}$ as a risk factor for developing CAD in postmenopausal women and to assess the serum $\operatorname{Lp}_{(\text {a) }}$ as a laboratory tool for the prevention of CAD. Postmenopausal women having significantly higher level of serum $\mathrm{Lp}_{(\mathrm{a})}$ may adopt anti-atherogenic lifestyle and diet. These are regular physical activity, maintenance of normal body weight, consumption of a diet low in saturated fat and high in fruits and vegetables.

\section{Materials and Methods:}

This case control study was carried out in the Department of Biochemistry, Dhaka Medical College, Dhaka, in collaboration with the Department of Immunology, Bangladesh Institute of Research and Rehabilitation in Diabetes, Endocrine and Metabolic Diseases (BIRDEM), Dhaka, during the period of July 2005 to June 2006. All the subjects were randomly selected from community and grouped as Group A, postmenopausal women as case and Group B, premenopausal women as control. Group A includes 30 women of age range 55-70 years, and Group B includes 40 women of age range $25-45$ years. Group $B$ again subdivided into $\mathrm{B}_{1}$ and $\mathrm{B}_{2}$. Group $\mathrm{B}_{1}$ comprises reproductive age of female having ages between 25-35 years and Group $B_{2}$ comprises reproductive age of female having age between 36-45 years. By taking history and doing clinical examination and laboratory investigations, diabetes mellitus, hypertension, malignant disease, liver disease, thyroid disease, renal disease, medication of oral contraceptive and obese (BMI $>30$ ) were excluded from study subjects. Ethical clearance for the study was taken from the Ethical Review Committee of Dhaka Medical College, Dhaka. Informed written consent was taken from all study subjects. Prior to sample collection, all the subjects were cordially requested to remain on 12-hour fast from $8 \mathrm{pm}$ to 8am next morning. At end of 12 hour fasting, $6 \mathrm{ml}$ venous blood was collected from all study subjects with full aseptic precaution. One milliliter blood was kept in fluoride containing oxalated test tube and $5 \mathrm{ml}$ in plain test tube. Oxalated blood was centrifuged, and the separated plasma used for estimation of plasma glucose immediately to exclude diabetes mellitus. Five milliliters blood in plain test tube was allowed to clot and centrifuge. Separated serum was then collected in Eppendorf and preserved at $-35_{0} \mathrm{C}$ after proper labeling, and late on used for the measurement of lipid 
profile and $\mathrm{Lp}_{(\mathrm{a})}$ concentration. All data were recorded systematically in a preformed data collection form and were expressed as their mean values $\pm \mathrm{SD}$. Mean values of the findings were compared between groups. Unpaired student ' $t$ ' test were used to see the level of significance. Confidence limit 95\% ( $p<0.05$ ) was taken as level of significance. All the statistical analyses were performed by using SPSS version 11.0.

\section{Result:}

Total 70 women were selected for this study. Selected women were grouped as group A, 30 postmenopausal women and group B, 40 women within reproductive age were selected. Group B again divided into two groups, group $\mathrm{B}_{1} 20$ women of 25-35 years age range and group $\mathrm{B}_{2}$ another 20 women of 26-45 years age range (Table-I). Serum $\mathrm{Lp}_{(\mathrm{a})}$ of all groups was measured. Concentration of serum Lp(a) in different groups was expressed as their mean value in $\mathrm{mg} / \mathrm{dl}$. Table-II shows the serum $\mathrm{Lp}_{(\mathrm{a})}$ in different study groups, which in group $A$, group $B_{1}$ and $B_{2}$ were $35.77 \pm 31.90 \mathrm{mg} / \mathrm{dl}, 18.40 \pm 11.46 \mathrm{mg} / \mathrm{dl}$ and $19.20 \pm 14.89 \mathrm{mg} / \mathrm{dl}$. Comparison of mean serum $\mathrm{Lp}_{(\mathrm{a})}$ concentration between different groups are shown in table-III.

\section{Table-I}

Grouping of the study subjects.

\begin{tabular}{lcc}
\hline Group & Number of subjects(n) & Mean \pm SD \\
\hline $\mathrm{A}$ & 30 & $59.67 \pm 3.14$ \\
$\mathrm{~B}_{1}$ & 20 & $31.15 \pm 2.89$ \\
$\mathrm{~B}_{2}$ & 20 & $39.40 \pm 2.85$ \\
\hline
\end{tabular}

Table - II

Serum lipoprotein(a) levels among study subjects.

\begin{tabular}{lcc}
\hline Group & $\begin{array}{c}\text { Number of } \\
\text { subjects(n) }\end{array}$ & $\begin{array}{c}\text { Serum Lp } \\
(\mathrm{mg} / \mathrm{dl})\end{array}$ \\
\hline $\mathrm{A}$ & 30 & $35.77 \pm 31.90$ \\
$\mathrm{~B}_{1}$ & 20 & $18.40 \pm 11.46$ \\
$\mathrm{~B}_{2}$ & 20 & $19.20 \pm 14.89$ \\
\hline
\end{tabular}

Table - III

Comparison of serum $L p_{(a)}$ level among different groups.

\begin{tabular}{llc}
\hline Group & Mean \pm SD & P value \\
\hline A vs B $_{1}$ & $35.77 \pm 31.90$ vs $18.40 \pm 11.46$ & $<0.05^{*}$ \\
A vs B $_{2}$ & $35.77 \pm 31.90$ vs $19.20 \pm 14.89$ & $<0.05^{*}$ \\
$\mathrm{~B}_{1}$ vs $B_{2}$ & $18.40 \pm 11.46$ vs $19.20 \pm 14.89$ & $>0.05^{\mathrm{NS}}$ \\
\hline P value & reached from unpaired & t test, \\
*Significant, NSNot significant. &
\end{tabular}

\section{Discussion:}

Menopause is one of the stages of life in women. Many physiological and metabolic changes occur in women after menopause, which may increase the risk of coronary artery disease. It has been observed that serum lipids and lipoproteins are significantly altered as a consequence of the hormonal changes ${ }^{2}$. Classical lipoproteins are chylomicrons, VLDL, LDL and HDL. These are well established CAD risk factors ${ }^{13}$. Besides these classical lipoproteins, there is another special type of atherogenic lipoprotein, called lipoprotein(a) ${ }^{14}$. A good number of women suffering from major clinical events of atherosclerosis, surprisingly they present a normal lipid profile or normal classical lipoprotein patterns. In these classical normolipidaemic patients $\mathrm{Lp}_{(\mathrm{a})}$ has been found to be significantly elevated ${ }^{5}$. So increased $\mathrm{Lp}_{(\mathrm{a})}$ may be a useful marker of CAD among postmenopausal women.

In the present case control study, the serum lipoprotein and lipid profile in post menopausal women (group A) and women in reproductive age group (group $B_{1}$ and $B_{2}$ ) have been measured to observe the effect of menopause on plasma level of $\mathrm{Lp}_{(\mathrm{a})}$. Present study has revealed the mean $\mathrm{Lp}_{(\mathrm{a})}$ concentration, $35 \pm 31$ $\mathrm{mg} / \mathrm{dl}$ in group $\mathrm{A}$. In group $\mathrm{B}_{1}$ and $\mathrm{B}_{2}$, it was $18.40 \pm 11.46$ and $19.20 \pm 14.89 \mathrm{mg} / \mathrm{dl}$ respectively.

Study has shown mean serum $\mathrm{Lp}_{(\mathrm{a})}$ level is significantly higher in postmenopausal women group than in reproductive age group. Same phenomenon observed in other studies ${ }^{2,15}$. But when it was compared within the two groups of reproductive ages, there was no significant 
difference. The increased level of serum $\mathrm{Lp}_{(\mathrm{a})}$ is related to the decreased level of estrogen ${ }^{10}$. In this study, postmenopausal elevation of $\mathrm{Lp}_{(\mathrm{a})}$ may be due to decreased level of estrogen in menopause.

The Framingham offspring study ${ }^{16}$ showed that $\mathrm{Lp}_{(\mathrm{a})}$ values was Significantly higher in postmenopausal women than in premenopausal. Seven hundred, thirty-six premenopausal women and 647 postmenopausal women were participating in that study. $\mathrm{Lp}_{(\mathrm{a})}$ is a unique molecule comprising a lipoprotein resembling LDL particle that is covalently bound to $\operatorname{apo}_{(a)}$, a plasma glycoprotein. The individual characteristics of these 2 components are thought to be responsible for the apparent pathogenic role of $\mathrm{Lp}_{(\mathrm{a})}$, which has no known physiologic function.

The LDL-cholesterol likely contributes to atherogenesis, whereas $\operatorname{apo}_{(\mathrm{a})}$, similar in structure to plasminogen may promote thrombosis. Thus $\mathrm{Lp}_{(\mathrm{a})}$ may serve as a link between the pathogenic processes of atherosclerosis and thrombosis ${ }^{17}$.

The Heart and Estrogen/progestin Replacement Study (HERS) demonstrate that $\mathrm{Lp}_{(\mathrm{a})}$ is associated with recurrent CHD events in women. This association was independent of other significant predictors. The increased incidence of cardiovascular disease after menopause suggests that estrogen is an important inhibitor of atherosclerotic process in women. The positive effects may partly result from the influence of estrogen on serum lipids ${ }^{18} \cdot \mathrm{Lp}_{(\mathrm{a})}$ are associated with an increased risk of cardiovascular disease. Hormone replacement therapy causes a diminution in $\mathrm{Lp}_{(\mathrm{a})}$ concentration in postmenopausal women ${ }^{19}$. Diet, exercise and some drugs such as niacin may delay the appearance of risk factors for cardiovascular diseases, especially in postmenopausal women ${ }^{20}$.

Present study shows that $\mathrm{Lp}_{(\mathrm{a})}$, which is an atherogenic non-classical lipoprotein is increased in postmenopausal women. Therefore, increased $\mathrm{Lp}_{(\mathrm{a})}$ has got a positive association with menopause.

\section{Conclusion:}

As from review of other studies we find that $\mathrm{Lp}_{(\mathrm{a})}$ is associated with coronary artery disease( CAD), the increased $\mathrm{Lp}_{(\mathrm{a})}$ level in menopausal women may be a risk factor of CAD. Menopausal women may be screened for serum $\mathrm{Lp}_{(\mathrm{a})}$ and if it is found to be increased they may be advised to adopt antiatherogenic life style and diet.

\section{Conclusion:}

As from review of other studies we find that $\mathrm{Lp}_{(\mathrm{a})}$ is associated with coronary artery disease( $\mathrm{CAD})$, the increased $\mathrm{Lp}_{(\mathrm{a})}$ level in menopausal women may be a risk factor of CAD. Menopausal women may be screened for serum $\mathrm{Lp}_{(\mathrm{a})}$ and if it is found to be increased they may be advised to adopt antiatherogenic life style and diet.

\section{References:}

1. Boon NA, Colledge NR, Walker BR. Endocrine diseases, In: Strachan MWJ, Walker BR. eds. Davidson's principles and practice of medicine. $20^{\text {th }}$ ed. Edinburgh: Churchill Livingstone; 2006: p.763.

2. Sposito AC, Mansur AP, Maranhao RC, Martinez TRL, Aldrighi JM, Ramires JAF. Triglyceride and lipoprotein(a) are markers of coronary artery disease severity among postmenopausal women. Maturitas 2001; 39: 2003-8.

3. Utermann G. The mysteries of lipopeotein(a). Science 1989; 246: 904-10.

4. McLean JW, Tomlison JE, Kuang WJ, Eaton DL, Chen EY, Fless GM, et al. cDNA sequence of human apolipoprotein(a) is homologous to plasminogen. Nature 1987; 300: 132-7.

5. Christopher R, Kailasanatha KM, Nagaraja D, Tripathi M. Case control study of serum lipoprotein(a) and apolipoprotein A-1 and B in stroke in the young. Acta Neurol Scand 1996; 94: 127-30.

6. Grainger DJ, Kirchenlohr HL, Metcalfe JC, Weissberg PL, Wade DP, Lawn RM. Proliferation of human smooth muscle cells promoted by lipoprotein(a). Science 1993; 260: 1655-8.

7. Murai A, Miyahara T, Fujimoto N, Matsuda M, Kameyama M. Lp(a) lipoprotein as a risk factor for coronary heart disease and cerebral infarction. Atherosclerosis 1986; 59: 199-204.

8. Yi-yi $Z$, Jun-jun W, Ping X. Increased lipoprotein(a) as an independent risk factor for cardiovascular and cerebrovascular disease. Chinese Med J 1993; 106: 597-600. 
9. Champ PC, Harvey RA. Cholesterol and steroid metabolism. In: Lippincott's illustrated reviews: biochemistry $3^{\text {rd }}$ ed. Philadelphia: Lippincott Williums \& Wilkins; 2005: p. 217-42.

10. Henriksson P, Angelin B, Berglund L. Hormonal regulation of serum $\mathrm{Lp}(\mathrm{a})$ levels. J Clin Invest 1992; 89: 1166-71.

11. Jhuma KA. Association of apo(a) with myocardial infarction [MPhil thesis]. Dhaka: University of Dhaka.

12. Jurgens G, Koltringer P. Lipoprotein(a) in ischemic cerebrovascular disease: a new approach to the assessment of risk for storke. Neurology 1987; 37: 513-5.

13. Hachinski V, Grafagnino C, Beaudry M, Bernier G, Buck C, Donner A, et al. Lipids and stroke: a paradox resolved. Arch Neurol 1996; 53: 303-8.

14. Guyton AC, Hall JE. Female physiology before pregnancy and the female hormones. In: Textbook of medical physiology. $11^{\text {th }}$ ed. New Delhi: Elsevier Saunders; 2006: p. 1011-25.

15. Bostom AG, Gagnon DR, Cupples A, Wilson PWF, Jenner JL, Ordovas JM, et al. A prospective investigation of elevated lipoprotein(a) detected by electrophoresis and cardiovascular disease in women: the Framingham heart study. Circulation 1994; 90: 1688-95.

16. Jenner JL, Ordovas JM, Lamon-Fava S, Schaefer MM, Wilson Pwf, Castelli WP, et al. Effects of age, sex and menopausal status on plasma lipoprotein(a) levels: The Framingham offspring study. Circulation 1993; 87: 1135-41.

17. Shlipak MG, Simon JA, Vittinghoff E, Lin F, Brarrett- Connor E, Knopp RH, et al. Estrogen and progestin, lipoprotein(a), and the risk of recurrent coronary heart disease events after menopause. JAMA 2000; 283: 1845-52.

18. Nordstrom P, Glader CA, Dahlen G, Birgander LS, Lorentzon R, Waldenstrom A, et al. Oestrogen receptor á gene polymorphism is related to aortic valve sclerosis in post menopausal women. $\mathrm{J}$ Int Med 2003; 254: 140-6.

19. Demonty I, Lamarche B, Jones PJH. Role of isoflavones in the hypocholesterolemic effect of soy. Nutrition Rev 2003; 61: 189-203.

20. Schoppen S, Perez-Granados AM, Carbajal A, Oubina P, Sanchez-Muniz FJ, Gomez-Gerique JA, et al. A sodium-rich carbonated mineral water reduces cardiovascular risk in postmenopausal women. J Nutr 2004; 134: 1058-63. 